\title{
Induction of oestrus and fertility in the anoestrous ewe with hormones and controlled lighting and temperature*
}

\author{
G. J. Mears $\dagger$, G. R. Van Petten $\ddagger$, W. H. Harris§, J. U. Bell $\Upsilon$ and \\ F. L. Lorscheider
}

Divisions of Medical Physiology and Pharmacology and Therapeutics, Faculty of Medicine, University of Calgary, Calgary, Alberta, Canada T2N 1 N4

\begin{abstract}
Summary. A programme consisting of 14 daily injections of progesterone (10 $\mathrm{mg})$ followed by single injection of PMSG (500 i.u.) and oestradiol-17ß (30 $\mu \mathrm{g}$ ), along with controlled temperature $\left(18-20^{\circ} \mathrm{C}\right)$ and lighting $(10 \mathrm{~h}$ light $/ 24 \mathrm{~h})$, was applied to 60 anoestrous ewes between late May and early August to induce reproductive activity. Breeding started within $24 \mathrm{~h}$ of the oestradiol injection and $80.0 \%$ of the ewes conceived at the induced oestrus. Dorset ewes had higher conception (95.2 versus $71.8 \%)$ and prolificacy (1.74 versus 1.52 fetuses/ewe) rates than did crossbred Suffolk ewes. Plasma progesterone concentrations during progesterone administration were significantly higher than those found during anoestrus and were generally lower in ewes which did not conceive than in those which did. The plasma progesterone data indicated that ovulation had occurrred in most of the ewes which were not pregnant at 90-100 days and that many may have been pregnant initially but then lost the conceptus.
\end{abstract}

\section{Introduction}

Numerous investigators have induced fertile cycling in the sheep during the anoestrous season. One of the approaches used has been to alter the hormonal milieu of the hypothalamic-pituitary system and the ovary by administration of exogenous hormones to the ewe (Gordon, 1963a, b, c; Brunner, Hansel \& Hogue, 1964; Hulet \& Foote, 1967; Mallampati, Pope \& Casida, 1971; Laster \& Glimp, 1974; Christenson, 1976). The use of exogenous hormones generally resulted in a high incidence of both behavioural oestrus and ovulation, but the conception rates for the induced oestrus during mid-anoestrus ranged from $21 \%$ (Gordon, 1963a) to 50\% (Brunner et al., 1964). Another approach has been to alter environmental stimuli, such as light and temperature, which act via higher nervous centres to modulate the reproductive cycling of sheep (Yeates, 1949; Godley, Wilson \& Hurst, 1966; Ducker, Thwaites \& Bowman, 1970; Ducker \& Bowman, 1972; Palmer, Phillips, Howland \& Ibrahim, 1972). This approach has frequently resulted in high conception rates but the length of time required until the onset of oestrus was usually large and variable. Both Yeates (1949) and Palmer et al. (1972) found that over 100 days of controlled environment was necessary before mating occurred. Attempts have also been made to induce oestrus in the ewe by combining the use of exogenous hormones and

* Reprint requests to: Dr F. L. Lorscheider.

† Present address: Agriculture Canada Research Station, Lethbridge, Alberta, Canada T1J 4B 1.

$¥$ Present address: Dean, Faculty of Pharmacy and Pharmaceutical Sciences, University of Alberta, Edmonton, Alberta, Canada T6G 2N8.

$\S$ Present address: Department of Biomedical Sciences, University of Guelph, Guelph, Ontario, Canada N1G 2 W 1.

If Present address: Department of Pharmacology, West Virginia University Medical Center, Morgantown, West Virginia 26506, U.S.A. 
environmental control (Vesely, 1975) but a significant additive effect on conception rate was not obtained. In the present report we describe a programme developed to satisfy our requirements for the rapid induction of a predictably timed and fertile oestrus during the ewe's normal anoestrous season. We combined the use of exogenous hormones with the control of light and temperature to simulate the hormonal milieu of the ovary and the hypothalamic-pituitary system during a natural breeding cycle and also the fall conditions under which natural breeding is initiated in western Canada.

\section{Materials and Methods}

Experimental animals. Twenty-one Dorset ewe-lambs and 39 crossbred Suffolk ewes and ewelambs were used. The 24 crossbred Suffolk ewes had all lambed at least once previously. The rams and ewes were sheared and brought into the medical vivarium where they were maintained in a controlled environment of $18-20^{\circ} \mathrm{C}$ and $10 \mathrm{~h}$ light $/ 24 \mathrm{~h}$. They were fed a commercially prepared pelleted all-in-one sheep ration (14\% protein) with water and trace-mineralized-salt blocks available ad libitum. Each ewe was injected (s.c.) with an emulsified solution of vitamins A (500000 i.u.), D (75000 i.u.) and E (50 i.u.) 8-10 days before the administration of hormones. Healthy animals were chosen for the programme and any ensuing health problems were promptly attended to.

Hormonal regimen. After the acclimatization period of 10 days hormones were administered to the ewes according to the following schedule.

(a) On Days 1-14, $10 \mathrm{mg}$ (Suffolk ewes) or $7.5 \mathrm{mg}$ (Dorset ewes) progesterone (delta 4pregnen-3,20-dione; Sigma Chemical Company, St. Louis, Missouri) were administered in $1 \mathrm{ml}$ soybean oil by daily s.c. injection in the axillary region. This amount of progesterone administered in corn oil has previously been demonstrated to be sufficient for synchronization of oestrus (Hunt, Addleman \& Bogart, 1971) and for induction of cycling in anoestrous ewes when treated for 12 days (Mallampati et al., 1971).

(b) On Day 15, 500 i.u. PMSG (Intervet Laboratories Limited, Bar Hill, Cambridge, U.K.) were administered in $2 \mathrm{ml}$ saline $(9 \mathrm{~g} \mathrm{NaCl} / 1)$ by i.m. injection in the gluteus muscle. Gordon (1971) found higher conception rates after treatment with 500 i.u. PMSG than with 250 or 750 i.u. given after progestagen treatment during late anoestrus.

(c) On Day 16, $30 \mu$ g oestradiol-17 $\beta$ (Sigma Chemical Company) was administered in $1 \mathrm{ml}$ ethanol by i.m. injection in the gluteus muscle. Oestradiol was included in this programme because small, properly timed doses will bring about an LH surge, starting 8-10 h after administration (Goding et al., 1969; Symons, Cummingham \& Saba, 1973), and ovulation (Hansel \& McEntee, 1970) in anoestrous ewes.

These injections were given at the same time of the day $(13: 30-14: 00 \mathrm{~h})$ whenever possible; occasionally at weekends the progesterone was injected up to $6 \mathrm{~h}$ earlier or later. Particular care was taken to ensure that the interval between the injection of PMSG and oestradiol-17 $\beta$ was always $24 \pm 1 \mathrm{~h}$. A new group of 4-6 ewes began this hormonal regimen each week between 20 May and 29 July 1975 . No natural breeding occurred in the remainder of the flock between 1 March and 23 August of that year.

Following the oestradiol injection on Day 16 the ewes were divided into two groups, each of which was confined with a fertile ram. The rams were switched to the opposite groups late on Day 17 and separated from the ewes late on Day 18. For the next 8 days the ewes were maintained in the controlled environment and then were returned to pasture.

Measurement of plasma progesterone. Blood samples were collected in heparinized tubes via jugular venepuncture before, during and after treatment of the ewes with progesterone. In 8 ewes blood samples were collected from each ewe at 2-day intervals during the 14 days before progesterone treatment (controls) and $22 \mathrm{~h}$ (range 20-24 h) after every 2 nd progesterone 
injection: all of these ewes subsequently conceived at the induced oestrus. In 9 other ewes blood samples were collected 1-2 $\mathrm{h}$ after the progesterone injections on Days 3 and 8: 5 of these ewes subsequently conceived during the induced oestrus. Blood samples were also collected from 36 ewes on the day of induced oestrus (Day 0) and on Days 10 and 16 following this oestrus: 27 of these ewes conceived during the induced oestrus.

The plasma obtained from the blood samples was stored at $-20^{\circ} \mathrm{C}$ until assayed. Progesterone levels were determined by the radioimmunoassay method of Lindner, Perel, Friedlander \& Zeitlin (1972) using rabbit anti-progesterone-11a-BSA serum (Miles Research Division, Elkhart, Indiana). The sensitivity was $0.05 \mu \mathrm{g} / \mathrm{ml}$ and the interassay coefficient of variation was $4.5 \%(n=10)$.

Determination of conception and prolificacy rates. All pregnant sheep from this programme were utilized for research involving chronic cannulation of the fetus (Van Petten, Mathison, Harris \& Mears, 1978). These sheep were routinely X-rayed for pregnancy at 90-100 days after mating and the conception data reported here are based on these results. The prolificacy data were obtained by uterine palpation during fetal surgery at approximately 110 days of gestation rather than from lambing data since not all ewes went to term.

Statistical analysis of data. The $\chi^{2}$ test for independence was used to compare conception rates for the two breeds of sheep. The two-tailed Student's $t$ test was used for all other comparisons of mean values.

\section{Results}

Breeding. After hormone treatment the ewes were observed every $1-2 \mathrm{~h}$ during the day and at least once in the evening for indications of oestrus. Initial behavioural oestrus was usually displayed $20-22 \mathrm{~h}$ after injection of oestradiol. Very occasionally overt behavioural oestrus was not observed but the number of ewes in this category was not counted.

Conception and prolificacy rates. These data are shown in Table 1. Values for Dorset ewelambs were greater than those for crossbred Suffolk ewe-lambs and ewes, while the Suffolk ewes had a higher conception rate $(75 \%)$ than did the Suffolk ewe-lambs (67\%). Conception rate was not correlated with the stage of the anoestrous season at which the resumption of cycling was induced.

One Dorset ewe aborted 5 extremely small fetuses at 97 days gestation.

Plasma progesterone concentrations before and during progesterone treatment. The mean \pm s.e.m. plasma progesterone concentration obtained from blood samples collected $22 \mathrm{~h}$ after the daily administration of progesterone to 8 ewes was double $(0.52 \pm 0.05 \mathrm{ng} / \mathrm{ml}, n=56)$ that

Table 1. Conception and prolificacy rates for 60 ewes bred at the first oestrus after the induction of reproductive activity in anoestrus

\begin{tabular}{|c|c|c|c|c|c|}
\hline \multirow[b]{2}{*}{ Breed } & \multicolumn{2}{|c|}{ Conception rate } & \multicolumn{3}{|c|}{ Prolificacy rate } \\
\hline & $\begin{array}{l}\text { No. of } \\
\text { ewes }\end{array}$ & $\begin{array}{c}\text { No. } \\
\text { pregnant (\%) }\end{array}$ & $\begin{array}{l}\text { No. } \\
\text { of ewes }\end{array}$ & $\begin{array}{l}\text { No. of } \\
\text { fetuses }\end{array}$ & $\begin{array}{l}\text { Rate } \\
\text { (s.d.) }\end{array}$ \\
\hline Dorset & 21 & $20(95 \cdot 2)^{*}$ & $19 \dagger$ & $33 \mp$ & $\begin{array}{c}1.74 \\
(0.65)\end{array}$ \\
\hline Crossbred Suffolk & 39 & $28(71 \cdot 8)^{*}$ & $27 \dagger$ & $41 \ddagger$ & $\begin{array}{c}1.52 \\
(0.70)\end{array}$ \\
\hline Total & 60 & $48(80 \cdot 0)$ & 46 & 74 & $\begin{array}{l}1.61 \\
(0.68)\end{array}$ \\
\hline
\end{tabular}

* Significantly different, $P<0.05$.

$\uparrow$ One ewe aborted after X-ray at 90-100 days but before surgery at 110 days and was not included.

$\ddagger$ Contained 2 sets of triplets. 
obtained when blood samples were collected from the same ewes before treatment $(0.26 \pm 0.02$ $\mathrm{ng} / \mathrm{ml}, n=56)(P<0.01)$. When the blood samples were collected $1-2 \mathrm{~h}$ after daily administration of progesterone, the plasma progesterone concentrations were significantly higher, compared to the 22-h progesterone concentration, for 5 ewes that conceived (6.98 $\pm 2.24 \mathrm{ng} / \mathrm{ml}, n=10, P<0.01)$ and 4 ewes that remained barren $(1.07 \pm 0.24 \mathrm{ng} / \mathrm{ml}, n=8$, $P<0.05)$ and the last 2 values were also significantly different from each other $(P<0.02)$.

A wide range in plasma progesterone concentrations was observed when ewes were sampled 1-2 $\mathrm{h}$ after progesterone treatment, but no consistent pattern was apparent. Of the ewes that became pregnant, 3 had very high progesterone concentrations $(15-20 \mathrm{ng} / \mathrm{ml})$ and the other 2 had very low values $(0.79$ and $0.81 \mathrm{ng} / \mathrm{ml})$ in one of the two samples obtained. Three of the ewes that did not conceive had plasma progesterone concentrations of $<1.0 \mathrm{ng} / \mathrm{ml}$ for both samples, whereas the other animal in this group had relatively high plasma progesterone concentrations for both samples $(1.78$ and $1.98 \mathrm{ng} / \mathrm{ml})$. All values were included in the calculations since their inclusion did not alter the statistical significance of the mean difference in plasma progesterone concentrations between the pregnant and non-pregnant ewes.

Table 2. Mean \pm s.e.m. plasma progesterone concentrations on Days 0,10 and 16 after the induction of oestrus (Day 0 ) in 36 anoestrous ewes

\begin{tabular}{lcccc}
\hline \multirow{2}{*}{$\begin{array}{c}\text { X-ray } \\
\text { diagnosis }\end{array}$} & $\begin{array}{c}\text { No. of } \\
\text { ewes }\end{array}$ & Day 0 & Day 10 & Day 16 \\
\cline { 3 - 5 } & 27 & $0.68 \pm 0.16$ & $5.00 \pm 0.92 \dagger$ & $4.01 \pm 0.70^{*}$ \\
Pregnant & 9 & $0.35 \pm 0.06$ & $2.88 \pm 0.70 \dagger$ & $1.41 \pm 0.43^{*}$ \\
Non-pregnant & & &
\end{tabular}

* Significantly different, $P<0.005$.

† Significantly different from the corresponding Day 0 value, $P<0.005$.

Plasma progesterone concentration after the induction of oestrus. The difference in plasma progesterone concentrations between the ewes that conceived and those that did not was significant only on Day 16 (Table 2). Progesterone levels rose in both groups of ewes by Day 10 but had decreased at Day 16 by $20 \%$ in the pregnant ewes and $51 \%$ in the non-pregnant ewes; neither decrease was significant because of the great variation obtained. This appeared to be random in the 27 ewes that conceived and ranged from 1.5 to $20 \mathrm{ng} / \mathrm{ml}$ for both Days 10 and 16, but the data obtained for Days 10 and 16 for the 9 ewes that did not conceive could be divided into two distinct groups. On Day 10, the plasma progesterone concentration in 3 of these ewes was $0.62 \pm 0.15 \mathrm{ng} / \mathrm{ml}$, similar to the concentration on Day 0. By Day 16, 4 of the ewes had low progesterone concentrations $(0.32 \pm 0.04 \mathrm{ng} / \mathrm{ml})$. The remaining ewes had significantly $(P<$ $0.005)$ higher plasma progesterone concentrations of $4.01 \pm 0.64 \mathrm{ng} / \mathrm{ml}$ on Day $10(\mathrm{~N}=6)$ and $2.28 \pm 0.47 \mathrm{ng} / \mathrm{ml}$ on Day $16(\mathrm{~N}=5)$.

Progesterone data were obtained during progesterone treatment and following the induction of oestrus in 4 of the non-pregnant ewes. One had low plasma progesterone concentrations during treatment and on Days 10 and 16 after oestrus. Two had low progesterone concentrations during progesterone treatment and elevated values on Days 10 and 16. The 4th ewe had high plasma progesterone concentrations in both samples taken during treatment and on Days 10 and 16 after oestrus.

\section{Discussion}

This programme was developed to satisfy our requirements for a rapidly induced and fertile oestrus during the sexually quiescent season of the sheep. The results indicate a high degree of 
success for both of these requirements. The ewes usually demonstrated behavioural oestrus within $24 \mathrm{~h}$ of the final hormonal injection, thus permitting the planning of a breeding schedule that coincided with the need for pregnant ewes for fetal surgery approximately 110 days later (Van Petten et al., 1978). This is in marked contrast to previous studies in which alteration of the environmental temperature and light without concurrent hormonal treatment resulted in a long and variable time before the induction of oestrus (Yeates, 1949; Palmer et al., 1972). Furthermore, the induced oestrus was highly fertile in that $80 \%$ of all ewes treated were pregnant when X-rayed 90-100 days after exposure to the rams at the induced oestrus. The conception rate of $95.2 \%$ for the Dorset ewe-lambs was exceptionally high for a one-cycle-only breeding, possibly because Dorset sheep are easier to breed throughout the year (Hansel \& McEntee, 1970; Laster \& Glimp, 1974). The high conception rates reported here are in contrast to those of Mallampati et al. (1971) who obtained an induced lambing rate of only $38 \%$ during the comparable state of anoestrus of May through August. Others have reported conception rates similar to that of our crossbred Suffolks, but only when induction occurred in early or late anoestrus (Brunner et al., 1964) or after two or more consecutive breedings (Gordon, 1963b; Hulet \& Foote, 1967; Laster \& Glimp, 1974; Christenson, 1976).

The prolificacy rates obtained following breeding at the induced oestrus were similar to those routinely observed in our flock for Dorsets and crossbred Suffolks after breeding at natural oestrus. With the possible exception of one Dorset ewe that aborted 5 fetuses, it would therefore appear that the high conception rates were achieved without the induction of superovulation in the ewes.

The extent of the contribution of the controlled environment to the success of this programme is difficult to ascertain. Exposure to similar light:dark ratios and temperatures was sufficient to induce a high incidence of cycling in anoestrous ewes (Godley et al., 1966). However, the 26 days of exposure to the controlled environment was less (5-110 days) than that reported to induce cycling (Yeates, 1949; Ducker \& Bowman, 1972; Palmer et al., 1972) but, presumably, it was sufficient to bring the ewes out of their deepest anoestrous state. Two observations indicate that controlling the environment may have influenced the outcome to some extent. First, there was a $100 \%$ conception rate in 8 ewes exposed to an additional 14 days of the controlled environment while pretreatment blood samples were being collected, although the overall rate of conception for crossbred Suffolks was $75 \%$. Second, in field trials in which environmental controls were not employed, lambing occurred in $65 \%$ of the ewes in mixed-breed flocks on an identical hormone regimen during March and April. The controlled temperature that the ewes were exposed to following breeding may have also contributed to the high conception rate by preventing the early embryo loss (0-8 days) reported to occur following exposure of ewes to high temperatures $\left(32-38^{\circ} \mathrm{C}\right)$ immediately after mating (Dutt, 1963; Thwaites, 1967).

The basal plasma progesterone concentrations observed were consistently low for all ewes sampled, indicating that these animals were in an anoestrous state before progesterone treatment. The value of $0.26 \pm 0.02 \mathrm{ng} / \mathrm{ml}$ was similar to that previously reported for anoestrous ewes (Saba, Cunningham, Symons \& Millar, 1975). Maximum plasma progesterone levels for the luteal phase of the oestrous cycle of the cycling ewe have been reported to be $2.4-3.7 \mathrm{ng} / \mathrm{ml}$ (Stabenfeldt, Holt \& Ewing, 1969; Robertson \& Sarda, 1971; Pant, Hopkinson \& Fitzpatrick, 1977). Cunningham, Saba \& Millar (1975) have suggested that it may be necessary to maintain plasma progesterone levels above $1 \mathrm{ng} / \mathrm{ml}$ for $10-14$ days in order to induce cycling in anoestrous ewes. The daily injections of progesterone employed in the present study resulted in a pronounced effect on plasma progesterone concentrations. Ewes that conceived attained peak plasma progesterone concentrations higher than previously reported luteal phase values and were mostly $>1 \mathrm{ng} / \mathrm{ml}$ on each occasion studied. By contrast, of 4 ewes that did not conceive and for which data during progesterone injections were obtained, only one had plasma progesterone concentrations that approached those of the luteal phase of the normally cyclic 
ewe. The remaining 3 ewes consistently had plasma progestone concentrations $<1 \mathrm{ng} / \mathrm{ml}$. The significantly lower plasma progesterone concentrations in these ewes may have been due to poor absorption of progesterone from the s.c. injection site or to faster metabolic degradation of progesterone. However, it is unlikely that metabolic degradation would vary to the extent necessary to attain the wide range in plasma progesterone concentrations observed $1-2 \mathrm{~h}$ after treatment with progesterone.

Only one plasma sample was taken during any 24-h interval and therefore it is not known if plasma progesterone concentrations in the ewes that did not conceive were low throughout the day following progesterone treatment, thereby failing to achieve the concentrations suggested by Cunningham et al. (1975) to be necessary to induce oestrus. We also do not know if behavioural oestrus occurred in the 12 ewes that did not conceive since mating records for individual ewes were not kept. However, the progesterone data obtained for 9 of these ewes for the 16 days following the date of expected oestrus indicate that ovulation occurred in the majority of these ewes since they exhibited an elevated mean plasma progesterone concentration on Day 10 (see Table 2) similar to the peak luteal-phase progesterone concentration in plasma reported for cyclic ewes (Stabenfeldt et al., 1969; Robertson \& Sarda, 1971; Pant et al., 1977). Examination of the progesterone data for individual animals on Day 10 revealed that 3 out of the 9 ewes had low progesterone concentrations, indicative of no ovulation, whereas the other 6 had ovulated and had progesterone concentrations similar to those of ewes which were found to be pregnant. Ovulation had occurred in 2 of the 6 ewes despite their progesterone concentrations being $<1$ $\mathrm{ng} / \mathrm{ml}$ during progesterone treatment.

Apparent ovulation without conception often occurs when anoestrous ewes are induced to cycle (Hackett et al., 1975; Saba et al., 1975). This may be due to failure of fertilization or embryo loss. One of the ewes that did not conceive, but apparently ovulated, had a low plasma progesterone concentration on Day 16, indicative of fertilization failure (Robertson \& Sarda, 1971), but the other 5 ewes still had elevated progesterone concentrations on Day 16, suggesting conception (Robertson \& Sarda, 1971) but loss of the conceptus before the time of X-ray. It is possible that the levels of progesterone achieved during progesterone treatment were sufficient to induce ovulation but were insufficient to prepare the uterus for embryo maintenance. On the other hand, this may be normal embryonic wastage (Burfening, Friedrick \& Van Horn, 1977).

The development of this programme was made possible through the generous support of the Alberta Heart Foundation and the Medical Research Council of Canada. We are indebted to P. van Muyden for his excellent assistance during development of this programme, to J. Neufeld for assaying the plasma progesterone, and to Dr R. B. Church for supplying the PMSG.

\section{References}

Brunner, M.A., Hansel, W. \& Hogue, D.E. (1964) Use of 6-methyl-17-acetoxyprogesterone and pregnant mare serum to induce and synchronize estrus in ewes. $J$. Anim. Sci. 23, 32-36.

Burfening, P.J., Friedrick, R.L. \& Van Horn, J.L. (1977) Estimates of early embryonic loss in ewes mated to rams selected for high and low prolificacy. Theriogenology 7, 285-291.

Christenson, R.K. (1976) Effect of short-term progestogen treatment on induction of estrus and lambing in anestrous ewes. J. Anim. Sci. 43, 795801 .

Cunningham, N.E., Saba, N. \& Millar, P.G. (1975) Release of progesterone from silicone rubber implants in vitro, and the effects of the implants on plasma progesterone levels in sheep. J. Reprod. Fert. 43, 555-558.
Ducker, M.J. \& Bowman, J.C. (1972) Photoperiodism in the ewe. 5. An attempt to induce sheep of three breeds to lamb every eight months by artificial daylength changes in a non-light-proofed building. Anim. Prod. 14, 323-334.

Ducker, M.J., Thwaites, C.J. \& Bowman, J.C. (1970) Photoperiodism in the ewe. 2. The effects of various patterns of decreasing daylength on the onset of oestrus in Clun Forest ewes. Anim. Prod. 12, 115123.

Dutt, R.H. (1963) Critical period for early embryo mortality in ewes exposed to high ambient temperature. J. Anim. Sci. 22, 713-719.

Goding, J.R., Catt, R.J., Brown, J.M., Kaltenbach, C.C., Cumming, I.A. \& Mole, B.J. (1969) Radioimmunoassay for ovine luteinizing hormone. Secretion of luteinizing hormone during estrus and following 
estrogen administration in the sheep. Endocrinology $85,133-142$.

Godley, W.L., Wilson, R.L. \& Hurst, V. (1966) Effect of controlled environment on the reproductive performance of ewes. J. Anim. Sci. 25, 212-216.

Gordon, 1. (1963a) The induction of pregnancy in the anoestrous ewe by hormonal therapy. II. Progesterone-pregnant mare's serum application in anoestrus. J. agric. Sci., Camb. 60, 43-66.

Gordon, I. (1963b) The induction of pregnancy in the anoestrous ewe by hormonal therapy. III. The use of repeated progesterone-pregnant mare's serum therapy. J. agric. Sci., Camb. 60, 67-70.

Gordon, I. (1963c) The induction of pregnancy in the anoestrous ewe by hormonal therapy. IV. Simplification of hormonal procedures. J. agric. Sci., Camb. 60, 71-76.

Gordon, I. (1971) Induction of early breeding in sheep by standard and modified progestagen-PMS treatments. J. agric. Sci., Camb. 76, 337-341.

Hackett, A.J., Inskeep, E.A., Ainsworth, L., Heaney, D.P., Peters, H.F. \& Robertson, H.A. (1975) Induction of estrus mating and lambing of sheep in total confinement. Can. J. Anim. Sci. 55, 787-788, Abstr.

Hansel, W. \& McEntee, K. (1970) Female reproductive processes. In Duke's Physiology of Domestic Animals, 8th edn, pp. 1253-1297. Ed. M. J. Swenson. Cornell University Press, Ithaca.

Hulet, C.V. \& Foote, W.C. (1967) Induction of fertile estrus in lactating and dry anestrous ewes using oral progestogens and repeated PMS treatment. J. Anim. Sci. 26, 545-548.

Hunt, W.L., Addleman, D. \& Bogart, R. (1971) Induction of multiovulation in the ewe following synchronization of estrus. J. Anim. Sci. 32, 491-495.

Laster, D.B. \& Glimp, H.A. (1974) Influence of breed on response to exogenous hormones in estrous and anestrous ewes. J.Anim. Sci. 39, 1129-1135.

Lindner, H.R., Perel, E., Friedlander, A. \& Zeitlin, A. (1972) Specificity of antibodies to ovarian hormones in relation to the site of attachment of the steroid hapten to the peptide carrier. Steroids 19, 357-375.

Mallampati, R.S., Pope, A.L. \& Casida, L.E. (1971) Breeding patterns in Targhee ewes and ewe lambs throughout the year. J. Anim. Sci. 33, 1278-1287.
Palmer, W.M., Phillips, G.D., Howland, B.E. \& Ibrahim, E.A. (1972) Effect of daylength on reproduction of ewes. Proc. West. Sect. Am. Soc. Anim. Sci. 23, 318321.

Pant, H.C., Hopkinson, C.R.N. \& Fitzpatrick, R.J. (1977) Concentration of oestradiol, progesterone, luteinizing hormone and follicle-stimulating hormone in the oestrous cycle. J. Endocr. 73, 247-255.

Rich, T.D. \& Alliston, C.W. (1970) Influence of programmed circadian temperature changes on the reproductive performance of ewes. J. Anim. Sci. 30, 966-969.

Robertson, H.A. \& Sarda, I.R. (1971) A very early pregnancy test for mammals: its application to the cow, ewe and sow. J. Endocr. 49, 407-419.

Saba, N., Cunningham, N.F., Symons, A.M. \& Millar, P.G. (1975) The effect of progesterone implants on ovulation and plasma levels of LH, FSH and progesterone in anoestrous ewes. J. Reprod. Fert. 44, 59-68.

Stabenfeldt, G.H., Holt, J.A. \& Ewing, L.L. (1969) Peripheral plasma progesterone levels during the ovine estrous cycle. Endocrinology 85, 11-15.

Symons, A.M., Cunningham, N.F. \& Saba, N. (1973) Oestrogen-induced LH surges in the anoestrous and cyclic ewe. J. Reprod. Fert. 35, 569-571.

Thwaites, C.J. (1967) Embryo mortality in the heat stressed ewe. I. Influence of breed. J. Reprod. Fert. 14, 5-14.

Van Petten, G.R., Mathison, H.J., Harris, W.H. \& Mears, G.J. (1978) Chronic preparation of the pregnant ewe and fetus for pharmacologial research: the placental transfer and fetal effects of bunitrolol. $J$. Pharmacol. Methods 1, 45-60.

Vesely, J.A. (1975) Induction to lamb every eight months in two breeds of sheep by light control with or without hormone treatment. Anim. Prod. 21, 165174.

Yeates, N.T.M. (1949) The breeding season of sheep with particular reference to its modification by artificial means using light. J. agric. Sci., Camb. 39, $1-42$.

Received 8 March 1979 